\title{
Extracellular proteinases from Micrococcus GF: I. Factors affecting growth and production *
}

\author{
GD García de Fernando **, PF Fox \\ Department of Food Chemistry, University College, Cork, Ireland
}

(Received 19 September 1990; accepted 30 January 1991)

\begin{abstract}
Summary - The optimum temperature for growth of and extracellular proteinase production by Micrococcus GF was $\approx 30^{\circ} \mathrm{C}$. Growth was more rapid and proteolytic activity was enhanced by aeration. The microorganism grew and was able to produce extracellular proteinase on casaminoacids, gelatin, phytone peptone, glutamic acid and glutamine, but not on the other amino acids as the sole carbon/nitrogen source. Proteolytic activity decreased after the early exponential phase when Micrococcus GF was grown either on $1 \%$ casaminoacids or $1 \%$ gelatin, but not when grown on casaminoacids plus gelatin or phytone peptone. $\mathrm{NH}_{4} \mathrm{Cl}$ had an inhibitory effect on growth rate, but it affected neither the proteolytic activity nor the final bacterial count when the microorganism grew on organic $\mathrm{N}$ plus $\mathrm{NH}_{4} \mathrm{Cl}$. When Micrococcus GF was grown at different phytone peptone concentrations, the shortest generation time was observed with $2 \%$ phytone peptone; proteolytic activity was constant in the range 1-2\% phytone peptone. Glucose and maltose did not affect proteinase production, but the generation time was increased by $\geq 1 \%$ glucose. Maltose had a slight inhibitory effect on growth as well as on proteinase production. Addition of $\mathrm{NaCl}$ to the culture medium supressed proteinase production by Micrococcus GF. The shortest generation time was observed in $2 \% \mathrm{NaCl}$, and the microorganism was able to grow in phytone peptone broth $(2 \%)$ containing $12 \%$, but not $14 \% \mathrm{NaCl}$.
\end{abstract}

\section{Micrococcus / growth / extracellular proteinase production}

Résumé - Protéinases extracellulaires de Micrococcus GF : I. Facteurs affectant la croissance et la production. La température optimale observée pour la croissance de Micrococcus GF et la production de protéinase extracellulaire est de $\approx 30^{\circ} \mathrm{C}$. Une aération augmente la croissance et stimule l'activité protéolytique. Le microorganisme se développe et produit une protéinase extracellulaire sur des sources azotées telles que acides aminés, gélatine, peptone phytone, acide glutamique, glutamine. II n'y a pas croissance lorsque on utilise une source unique de carbone/azote.

Quand Micrococcus GF est cultivé sur une source d'acides aminés à $1 \%$ ou de la gélatine 1\%, l'activité protéolytique est réduite après la phase exponentielle précoce alors que ce n'est pas le cas sur d'autres sources d'acides aminés additionnés de gélatine ou de peptone phytone. Sur milieu organique azoté, le taux de croissance de Micrococcus GF est inhibé par $\mathrm{NH}_{4} \mathrm{Cl}$, mais ce dernier $n^{\prime}$ affecte ni l'activité protéolytique ni le dénombrement final des bactéries.

\footnotetext{
* Part of this study was presented at the 19th Annual Food Science and Technology Research Conference, University College, Cork, 14-15 September, 1989.

** Correspondence and reprints: Departamento de Higiene y Tecnología de los Alimentos, Facultad de Veterinaria, 28040 Madrid, Spain.
} 
En faisant varier la concentration en peptone phytone, le temps de génération de Micrococcus était le plus court avec une concentration de $2 \%$. L'activité protéolytique était constante avec la peptone phytone de 1 à $2 \%$.

Le glucose et le maltose n'affectent pas la production de protéinase. Cependant quand la concentration de glucose était supérieure à $1 \%$, le temps de génération augmentait et le maltose avait un léger effet inhibiteur aussi bien sur la croissance que sur la production de protéinase.

L'addition de $\mathrm{NaCl}$ au milieu de culture réprime la production de protéinase par Microccocus $\mathrm{GF}$. Le temps de génération le plus court était observé avec $\mathrm{NaCl} 2 \%$ et le microorganisme était capable de croître dans un bouillon de peptone phytone (2\%) contenant $\mathrm{NaCl} 12 \%$ (et non $\mathrm{NaCl} 14 \%$ ).

\section{Micrococcus / croissance / production de protéinase extracellulaire}

\section{INTRODUCTION}

Micrococci commonly constitute the major fraction of the thermoduric population of milk (Nelson, 1981) and are therefore frequently present in pasteurized milk. They may come from the mammary glands, but normally the main source of contamination is external to the milk (Hammer and Babel, 1957).

Some species of the genus Micrococcus produce considerable amounts of extracellular proteinase(s) which may have a role in cheese ripening (Robertson and Perry, 1961), but there are few reports on the production of these enzymes, eg McDonald (1961) studied proteinase production in relation to the growth of a Micrococcus sp and Prasad et al (1984) reported the nutritional and environmental factors for optimum proteinase production by a different Micrococcus sp.

The objective of the present work was to study factors that affect the growth of and proteinase production by a Micrococcus isolate.

\section{MATERIALS AND METHODS}

The strain, Micrococcus GF, used was isolated from the surface of an Irish farmhouse blue cheese. The strain was identified by the standard procedures: Gram stain, motility, catalase production, effect of $\mathrm{NaCl}$ on growth, fermenta- tion of glucose, nitrate reduction and the ability to grow on inorganic nitrogen. The culture was maintained frozen in $2 \%$ phytone peptone broth (BBL Microbiology Systems, Cockeysville, MD, USA) until required.

The culture was cultivated in 100-ml volumes of a range of media (see below) in 500-ml Erlenmeyer flasks at $30^{\circ} \mathrm{C}$ on a rotating shaker operating at $\approx 100 \mathrm{rpm}$, unless otherwise stated. Aliquots were removed and assayed for growth and proteolytic activity.

The influence of aeration and temperature (raging from $22-38^{\circ} \mathrm{C}$ ) on the growth of and extracellular proteinase production by Micrococcus GF were assessed using $2 \%$ phytone peptone (BBL) with or without $5 \% \mathrm{NaCl}$. The effects of glucose, maltose and $\mathrm{NaCl}$ on these parameters were studied by adding these compounds separately at several concentrations to $2 \%$ phytone peptone.

For assessment of the significance of nitrogen sources (ammonium chloride, amino acids, casaminoacids, phytone peptone and gelatin), cells were washed 3 times in Ringer's solution and centrifuged at $15000 \mathrm{~g}$ at $4^{\circ} \mathrm{C}$ for $10 \mathrm{~min}$ in a Sorvall RC 5B centrifuge before inoculation. The nitrogenous compounds were added individually or in combination to the basal medium which was composed of $0.150 \% \quad \mathrm{KH}_{2} \mathrm{PO}_{4}$, $0.350 \% \mathrm{Na}_{2} \mathrm{HPO}_{4}, 0.012 \% \mathrm{MgSO}_{4} .7 \mathrm{H}_{2} \mathrm{O}$.

The effect of individual amino acids on the generation time of and proteinase production by Micrococcus GF growing on $1 \%$ gelatin was studied. Amino acid concentrations (mmol..$^{-1}$ ) were the same (theoretically) as in casaminoacids, ie alanine, 3.6; arginine, 2.2; asparagine, 3.1; aspartic acid, 2.2; cysteine, 0.2; glutamine, 7.4; glutamic acid, 8.7; glycine, 2.5; histidine, 1.9 ; isoleucine, 4.7 ; leucine, 7.4 ; lysine, 5.6 ; methionine, 2.1; phenylalanine, 3.3; proline, 10.2; 
serine, 6.8; threonine, 3.8; tryptophan, 0.6; tyrosine, 3.4 and valine, $6.2 \mathrm{mM}$.

Bacterial growth was estimated by measuring the turbidity of the cultures at $600 \mathrm{~nm} ; 1$ unit of growth represented a $\Delta \mathrm{A}_{600 \mathrm{~nm}}$ of 1 . Generation times were calculated from the data obtained during the exponential growth phase.

Proteinase activity was assayed using cell free supernatants (CFS) obtained by centrifuging a grown culture in a Sorvall RC $5 B$ centrifuge at $15000 \mathrm{~g}$ at $4{ }^{\circ} \mathrm{C}$ for $10 \mathrm{~min}$. CFS $(1 \mathrm{ml})$ was added to $1 \mathrm{ml}$ of a $0.8 \%$ solution of azocasein (Sigma) in $0.2 \mathrm{M}$ Tris- $\mathrm{HCl}$, buffer, $\mathrm{pH}$ 8.3. The mixture was incubated at $40{ }^{\circ} \mathrm{C}$ for $3 \mathrm{~h}$. The reaction was stopped by adding $1 \mathrm{ml}$ of $6 \%$ trichloroacetic acid and the mixture filtered through Whatman No 42 paper. Absorbance of the filtrate was measured at $440 \mathrm{~nm}$. A proteolytic activity unit was defined as the level of activity that gave a $\Delta \mathrm{A}_{440}$ of 1 at $40^{\circ} \mathrm{C}$ in $3 \mathrm{~h}$ per $\mathrm{ml}$ of CFS. Specific activity was defined as the proteolytic activity per growth unit $\left(\Delta \mathrm{A}_{600}=1\right)$.

\section{RESULTS}

The isolate was considered to be a Micrococcus sp since it was a $\mathrm{Gram}^{+}$, nonmotile, catalase ${ }^{+}$coccus that grew in more than one plane forming characteristic tetrads, grew in the presence of $12 \% \mathrm{NaCl}$ and did not ferment glucose. The strain grew as yellow, circular, smooth, convex colonies on nutrient agar. The only Micrococcus species that produce yellow pigment are $M$ varians and $M$ luteus. The isolate was similar to $M$ luteus because it could not reduce nitrate and did not ferment glucose. Within the characteristics studied the only one which did not correspond to the classification key of Kocur (1986) was growth on inorganic nitrogen agar: $M$ luteus grows on this medium, but Micrococcus GF did not.

When $2 \%$ phytone peptone with or without $5 \% \mathrm{NaCl}$ was used as growth medium, the shortest generation time was observed at $30^{\circ} \mathrm{C}$. Proteinase production was less at $22{ }^{\circ} \mathrm{C}$ than at higher temperatures and no significant difference were observed in the temperature range $26-37^{\circ} \mathrm{C}$.

Aeration reduced the generation time by at least $50 \%$ and markedly enhanced proteinase production, thus considerably improving the specific proteolytic activity (fig 1).
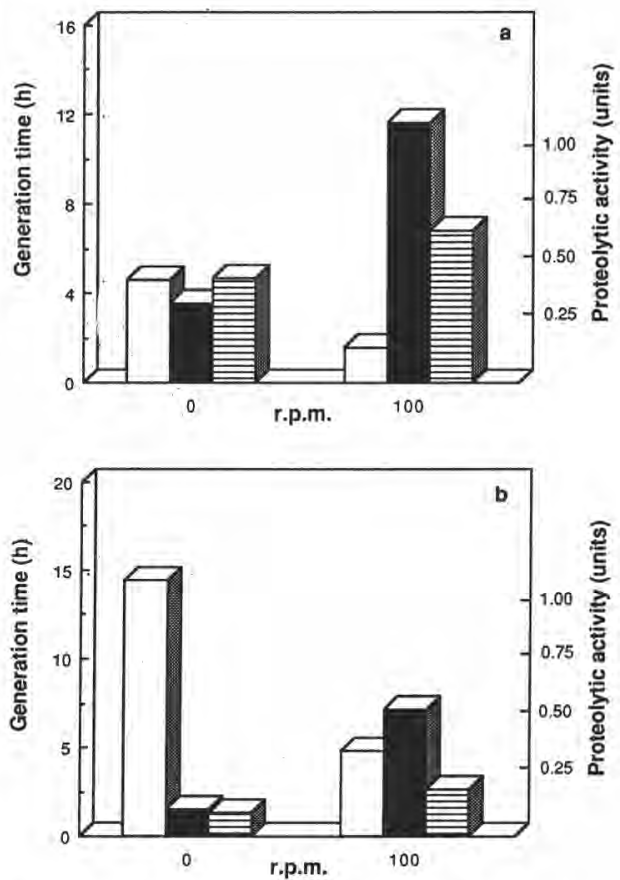

Fig 1. Effect of aeration (growth on a rotary shaker operating at $100 \mathrm{rpm}$ ) on the generation time of, and extracellular proteinase production by, Micrococcus GF grown in 2\% phytone peptone broth without $\mathrm{NaCl}$ (a) or containing $5 \% \mathrm{NaCl}$ (b) at $30^{\circ} \mathrm{C}$. $\square$ Generation time; Maximum proteolytic activity; 目 Specific activity.

Effet de l'aération (croissance dans un agitateur incubateur à 100 rpm) sur le temps de génération et sur la production des protéinases extracellulaires pour Micrococcus GF. Le milieu de croissance avait $2 \%$ de peptone phytone sans $\mathrm{NaCl}$ (a), et $5 \% \mathrm{NaCl}$ (b), à $30^{\circ} \mathrm{C}$. प Temps de génération; Maximum d'activité protéolytique; 目 Activité spécifique. 
The effect of the concentration of phytone peptone on the generation time of and extracellular proteolytic activity secreted by Micrococcus GF is shown in figure 2. The shortest generation time was observed at $2 \%$ phytone peptone. Proteolytic activity was detected at all phytone peptone concentrations tested, but increased markedly from 0.1 to $1 \%$ and decreased very slightly between 1 and $2 \%$ phytone peptone. However, $2 \%$ phytone peptone was selected for further studies since the generation time was shortest at this concentration.

When Micrococcus GF grew on $2 \%$ phytone peptone enriched with several amounts of glucose $(0-2.3 \%)$ or maltose $(0-3 \%)$, the shortest generation times were observed when Micrococcus GF grew without added sugar. Glucose had no effect on proteinase production, while maltose had a very slight inhibitory effect.

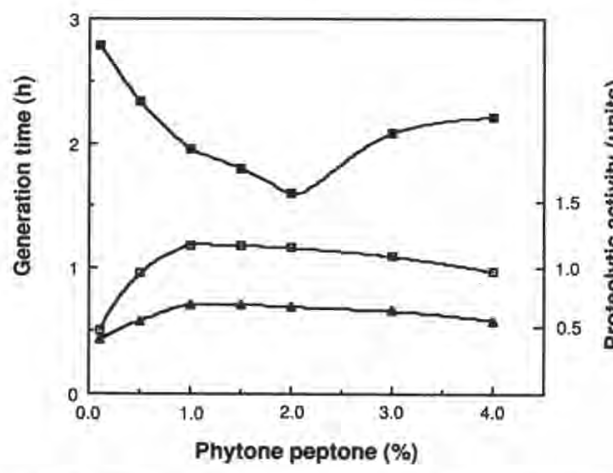

Fig 2. Effect of phytone peptone concentration on the generation time of, and extracellular proteinase production by Micrococcus GF at $30^{\circ} \mathrm{C}$ on a rotary shaker operating at $100 \mathrm{rpm}$. $\mathrm{Ee}$ neration time; $\square$ Maximum proteolytic activity; 目 Specific activity.

Effet de la concentration de peptone phytone sur le temps de génération et sur la production des protéinases extracellulaires pour Micrococcus $G F$, à $30^{\circ} \mathrm{C}$ dans un agitateur incubateur à $100 \mathrm{rpm}$. Temps de génération; $\square$ Maximum d'activité protéolytique;自 Activité spécifique.
The organism grew in $2 \%$ phytone peptone containing up to $12 \% \mathrm{NaCl}$ but not $14 \% \mathrm{NaCl}$; generation times were very long when the culture medium contained $>8 \% \mathrm{NaCl}$, being $>60 \mathrm{~h}$ in the presence of $12 \% \mathrm{NaCl}$. The shortest generation time was observed at $2 \% \mathrm{NaCl}$, although no marked differences were noted in the range $0-4 \% . \mathrm{NaCl}$ had an inhibitory effect on proteinase production at all concentrations investigated: specific activity decreased from 0.75 units at $0 \% \mathrm{NaCl}$ to 0.5 units at $6 \% \mathrm{NaCl}$ and to $<0.2$ units at $10 \%$ $\mathrm{NaCl}$. Since the proteinase was inhibited by $\mathrm{NaCl}$ at concentrations $>0.2 \mathrm{M}$ (see Garcia de Fernando and Fox, 1991; ie Part II of the article), these values were calculated taking into consideration the inhibitory effect of $\mathrm{NaCl}$ on the enzymatic reaction.

Micrococcus GF did not grow on the basal medium containing $0.4 \%$ glucose or maltose and $0.1 \% \mathrm{NH}_{4} \mathrm{Cl}$ as $\mathrm{N}$ source. It did grow and produce extracellular proteinase(s) in the basal medium containing $0.1 \%$ glutamine or glutamic acid, but not when any of the other amino acids at the same concentration were the sole $\mathrm{C} /$ $\mathrm{N}$ source. Growth curves for Micrococcus GF on these substrates are shown in figure 3. Lag phases were very long $(\approx 50 \mathrm{~h}$ ) in both cases; on glutamine, the exponential phase was shorter than when glutamic acid was the $\mathrm{C} / \mathrm{N}$ source, the generation times being 4.0 and $17.5 \mathrm{~h}$, respectively. Likewise, maximum cell density (absorbance) was higher when growing on glutamine. Proteinase production was very poor (around 0.1 units) throughout the growth cycle.

Casaminoacids $(1 \%)$, gelatin $(1 \%)$, gelatin $(1 \%)$ plus casaminoacids $(1 \%)$, and phytone peptone at several concentrations supported growth and proteinase production. Proteolytic activity and generation times in the complex $\mathrm{C} / \mathrm{N}$ sources tested 

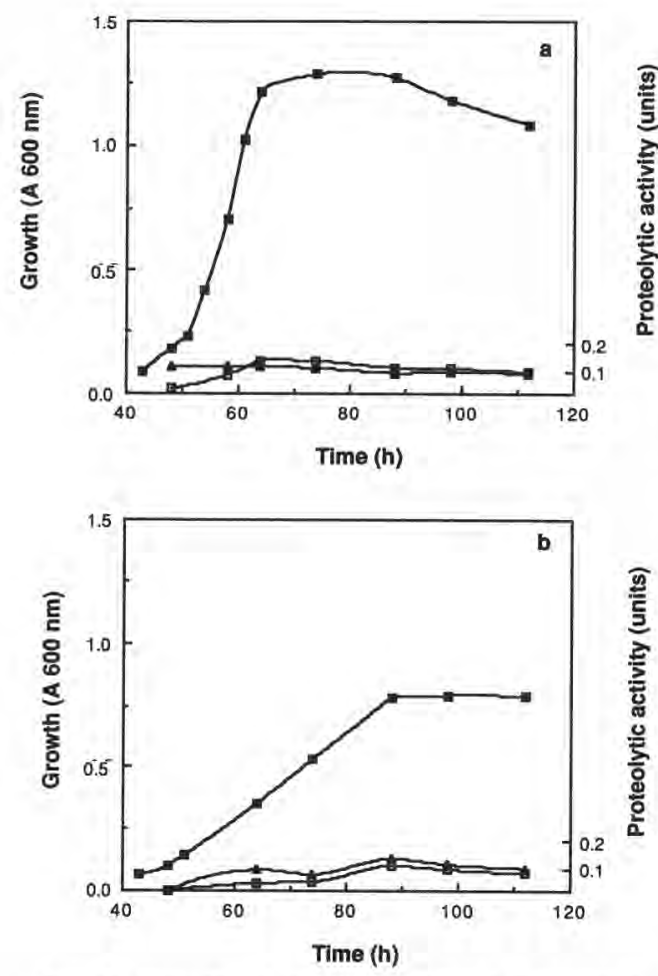

Fig 3. Growth of and extracellular proteinase production by Micrococcus GF grown in basal medium plus $0.1 \%$ glutamine (a) or $0.1 \%$ glutamic acid (b) at $30^{\circ} \mathrm{C}$ on a rotary shaker operating at $100 \mathrm{rpm}$. E $\mathrm{A} 600 \mathrm{~nm}$; $440 \mathrm{~nm}$; Specific activity.

Croissance et production des protéinases extracellulaires pour Micrococcus GF, dans un milieu basal avec $0,1 \%$ glutamine (a), ou $0,1 \%$ acide glutamique (b) à $30^{\circ} \mathrm{C}$ dans un agitateur incubateur à $100 \mathrm{rpm}$. 1 A $600 \mathrm{~nm} ; \square$ A $440 \mathrm{~nm}$; $\Delta$ Activité spécifique.

are shown in table I. Gelatin was the poorest $\mathrm{C} / \mathrm{N}$ source for growth, the generation time being twice that on phytone peptone at the same concentration. When Micrococcus GF grew on $1 \%$ phytone peptone, proteolytic activity was more than double that when growing on either gelatin (1\%) or casaminoacids (1\%). However, similar proteolytic activity was detected when Micro- coccus GF grew either on $1 \%$ casaminoacids plus $1 \%$ gelatin or on 1 or $2 \%$ phytone peptone.

The generation time for Micrococcus GF growing in $2 \%$ phytone peptone was shorter than when it grew in $1 \%$ casaminoacids plus $1 \%$ gelatin as $\mathrm{C} / \mathrm{N}$ source. Growth curves on these substrates are shown in figure 4 . The lag phases were around $10 \mathrm{~h}$ except when gelatin was the sole $\mathrm{C} / \mathrm{N}$ source (4b), when it was around $25 \mathrm{~h}$. Final absorbances were similar for all media, but the proteolytic activities differed. When Micrococcus GF grew on casaminoacids (4a) or gelatin (4b), proteinase activity increased until the end of the exponential phase. Activity decreased markedly in the case of casaminoacids during the early stationary phase and continued to decrease slightly thereafter; in the case of gelatin, activity decreased slightly. Proteinase production on casaminoacids plus gelatin (4d) or $1 \%(4 c)$ or $2 \%$ phytone peptone $(4 e)$ was similar: a marked increase was observed during the exponential phase, followed by a slight further increase during the early stationary phase and activity did not decrease during the stationary phase.

The effect of $\mathrm{NH}_{4} \mathrm{Cl}$ on the generation time of, and extracellular proteinase production by, Micrococcus GF is shown in table II. Generation time was longer in the presence of $\mathrm{NH}_{4} \mathrm{Cl}$, but proteolytic activity was not affected.

The influence of adding all the amino acids present in casaminoacids individually to $1 \%$ gelatin on growth and proteinase release was assessed. Glutamine was the only amino acid that markedly reduced the generation time (fig 5). Glutamic acid, glycine, isoleucine, phenylalanine, tryptophan and tyrosine reduced it to a lesser extent. Aspartic acid, leucine, lysine, proline, serine, threonine and valine had essentially no effect on the generation time, which 
Table I. Effect of supplementation of basal medium * with casaminoacids, gelatin or phytone peptone on the growth of and extracellular proteolytic production by Micrococcus GF.

Effet du supplement d'un milieu basal avec des casaminoacides, de la gélatine ou de la peptone phytone sur la croissance et la production des protéinases extracellulaires pour Micrococcus GF.

\begin{tabular}{lccc}
\hline C/N source & $\begin{array}{c}\text { Generation time } \\
(h)\end{array}$ & $\begin{array}{c}\text { Maximum activity } \\
\left(A_{440 \mathrm{~nm}}\right)\end{array}$ & $\begin{array}{c}\text { Specific activity } \\
\left(A_{440 \mathrm{~nm}} / A_{600 \mathrm{~nm}}\right)\end{array}$ \\
\hline $1 \%$ casaminoacids & 2.69 & 0.53 & 0.36 \\
$1 \%$ gelatin & 4.05 & 0.59 & 0.39 \\
$1 \%$ phytone peptone & 1.76 & 1.24 & 0.70 \\
$1 \%$ casaminoacids $+1 \%$ gelatin & 2.04 & 1.27 & 0.75 \\
$2 \%$ phytone peptone & 1.60 & 1.23 & 0.73 \\
\hline
\end{tabular}

" Basal medium: $0.150 \% \mathrm{KH}_{2} \mathrm{PO}_{4} ; 0.350 \% \mathrm{Na}_{2} \mathrm{HPO}_{4} ; 0.012 \mathrm{MgSO}_{4} .7 \mathrm{H}_{2} \mathrm{O}$

Table II. Effect of supplementing basal medium * containing various organic $\mathrm{N}$ sources with $\mathrm{NH}_{4} \mathrm{Cl}$ on the generation time of and extracellular proteolytic production by Micrococcus GF.

Effet du supplément d'un milieu basal qui a plusieurs sources des matières azotées avec $\mathrm{NH}_{4} \mathrm{Cl}$, sur le temps de génération et sur la production des protéinases extracellulaires pour Micrococcus GF.

\begin{tabular}{lccc}
\hline C/N source & $\begin{array}{c}\text { Generation time } \\
(h)\end{array}$ & $\begin{array}{c}\text { Maximum activity } \\
\left(A_{440} \mathrm{~nm}\right)\end{array}$ & $\begin{array}{c}\text { Specific activity } \\
\left(A_{440} \mathrm{~nm}^{\prime} A_{600 \mathrm{~nm}}\right)\end{array}$ \\
\hline $1 \%$ casaminoacids & 2.69 & 0.53 & 0.36 \\
$1 \%$ casaminoacids $+0.1 \% \mathrm{NH}_{4} \mathrm{Cl}$ & 3.38 & 0.38 & 0.24 \\
& & & 0.39 \\
$1 \%$ gelatin & 4.05 & 0.59 & 0.37 \\
$1 \%$ gelatin $+0.1 \% \mathrm{NH}_{4} \mathrm{Cl}$ & 8.43 & 0.55 & 0.70 \\
$1 \%$ phytone peptone & 1.76 & 1.24 & 0.70 \\
$1 \%$ phytone peptone $+0.1 \% \mathrm{NH}_{4} \mathrm{Cl}$ & 2.35 & 1.19 & 0.75 \\
$1 \%$ casaminoacids $+1 \%$ gelatin & 2.04 & 1.27 & 0.96 \\
$1 \%$ casaminoacids $+1 \%$ gelatin $+0.1 \% \mathrm{NH}_{4} \mathrm{Cl}$ & 2.40 & 1.29 & 0.73 \\
$2 \%$ phytone peptone & 1.60 & 1.23 & 0.59 \\
$2 \%$ phytone peptone $+0.1 \% \mathrm{NH}_{4} \mathrm{Cl}$ & 2.60 & 0.99 & \\
\hline
\end{tabular}

* Basal medium: $0.150 \% \mathrm{KH}_{2} \mathrm{PO}_{4} ; 0.350 \% \mathrm{Na}_{2} \mathrm{HPO}_{4} ; 0.012 \mathrm{HMgSO}_{4} .7 \mathrm{H}_{2} \mathrm{O}$. 

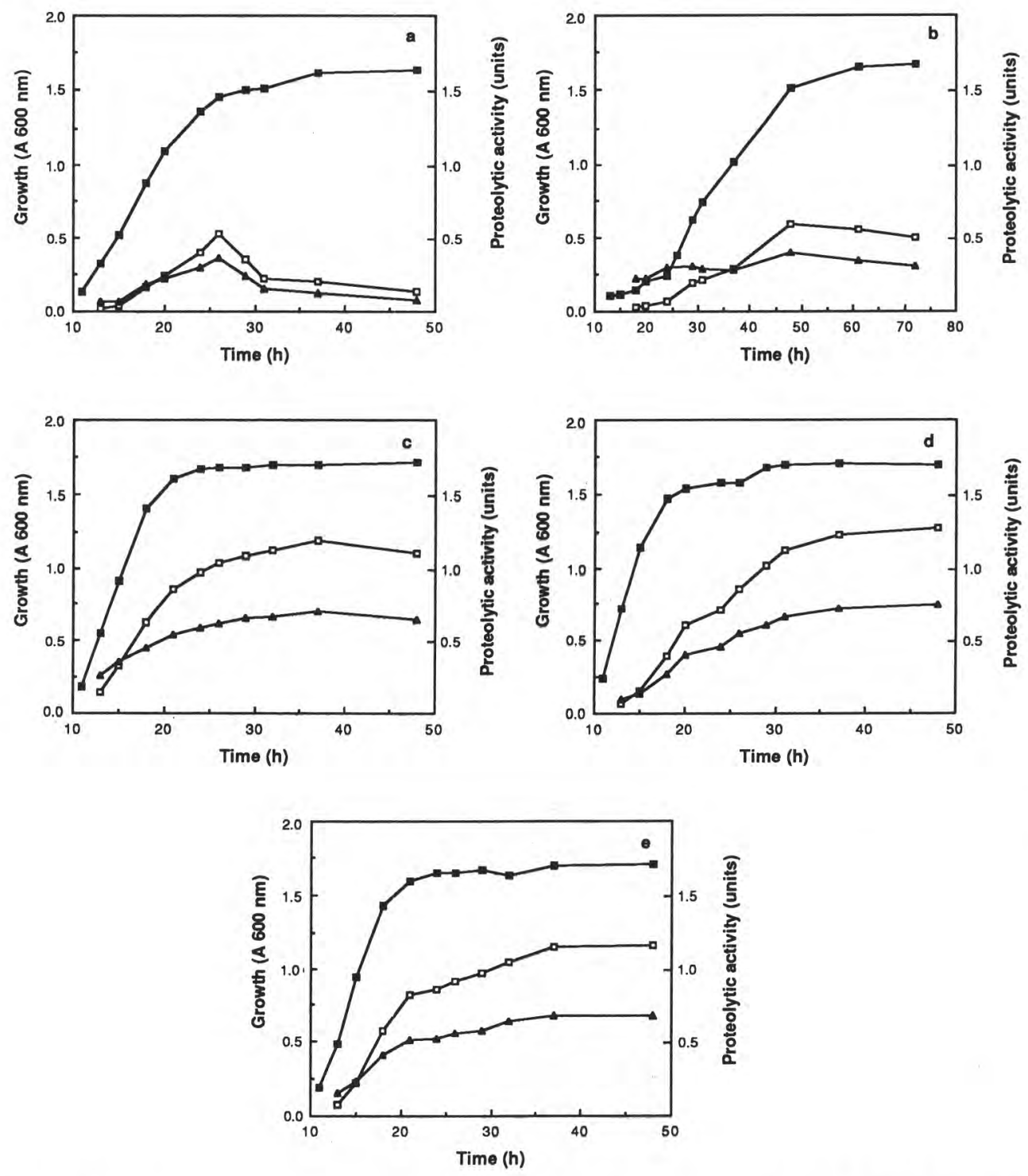

Fig 4. Growth of and extracellular proteinase production by Micrococcus GF grown in basal medium plus $1 \%$ casaminoacids (a), $1 \%$ gelatin (b), $1 \%$ phytone peptone (c), $1 \%$ casaminoacids plus $1 \%$ gelatin (d) or $2 \%$ phytone peptone (e) at $30^{\circ} \mathrm{C}$ on a rotary shaker operating at $100 \mathrm{rpm}$. $\mathrm{A} 600 \mathrm{~nm}$; A $440 \mathrm{~nm} ; \Delta$ Specific activity.

Croissance et production des protéinases extracellulaires pour Micrococcus GF, dans un milieu basal avec $1 \%$ casaminoacides (a), $1 \%$ gélatine (b), $1 \%$ peptone phytone (c), $1 \%$ casaminoacides plus $1 \%$ gélatine (d) ou $2 \%$ peptone phytone (e) à $30^{\circ} \mathrm{C}$ dans un agitateur incubateur à $100 \mathrm{rpm}$. $\mathbf{A} 600 \mathrm{~nm}$; $\square$ A $440 \mathrm{~nm} ; \Delta$ Activité spécifique. 

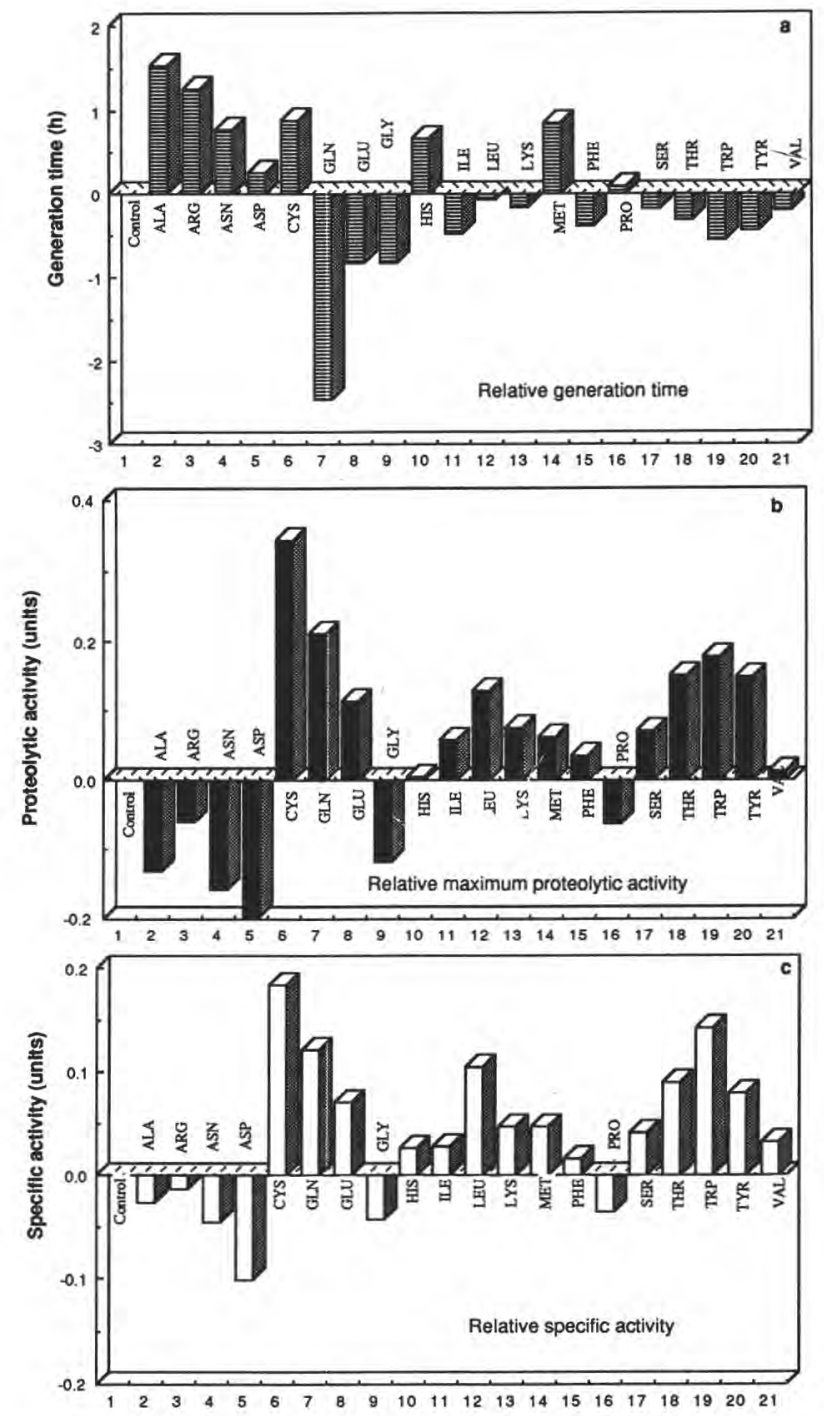

Fig 5. Effect of amino acids on (a) the generation time of, (b) proteinase production by and (c) specific activity of Micrococcus GF grown on a basal medium with $1 \%$ gelatin plus the corresponding amino acid as the $\mathrm{C} / \mathrm{N}$ source. Relative generation time (目). Relative proteolytic activity ( $\square$ ). Relative specific activity (]). 1, Control without amino acids; 2,Alanine 3.6 mmol..$^{-1} ; 3$,Arginine 2.2 mmol..$^{-1} ; 4$, Asparagine $3.1 \mathrm{mmol}^{-1}$; 5 , Aspartic acid $2.2 \mathrm{mmol}^{-1} \mathrm{I}^{-1} ; 6$ : Cysteine $0.2 \mathrm{mmol}^{-1} \mathrm{I}^{-1} ; 7$, Glutamine 7.4

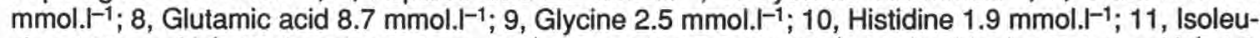
cine 4.7 mmol. $\mathrm{I}^{-1} ; 12$, Leucine $7.4 \mathrm{mmol}^{-\mathrm{I}^{-1}} ; 13$, Lysine $5.6 \mathrm{mmol} . \mathrm{I}^{-1} ; 14$, Methionine $2.1 \mathrm{mmol}^{-1}$; 15 , Phenylalanine $3.3 \mathrm{mmol}^{-1} \mathrm{I}^{-1} ; 16$, Proline $10.2 \mathrm{mmol}^{-\mathrm{I}^{-1}} ; 17$, Serine $6.8 \mathrm{mmol} . .^{-1} ; 18$, Threonine 3.8 mmol..$^{-1} ; 19$, Tryptophan 0.6 mmol..$^{-1} ; 20$, Tyrosine 3.4 mmol. $^{-1} .21$, Valine 6.2 mmol. $^{-1}$.

Effet des acides aminés sur (a) le temps de génération, (b) la production des protéinases et (c) l'activité spécifique de Micrococcus GF. Le milieu de croissance était un milieu basal avec $1 \%$ de gélatine plus les acides aminés correspondants qui donnent les sources de carbone/azote. Temps de génération relatif (目). Activité protéolytique relative (घ). Activité spécifique relative (口). 1, Contrôle sans acides aminés; 2, Alanine 3,6 mmol..$^{-1} ; 3$, Arginine 2,2 mmol..$^{-1} ; 4$, Asparagine 3,1 mmol..$^{-1} ; 5$, Acide aspartique $2,2 \mathrm{mmol}_{.1} \mathrm{I}^{-1} ; 6$, Cystéine $0,2 \mathrm{mmol}^{-\mathrm{I}^{-1}} ; 7$, Glutamine $7,4 \mathrm{mmol} . \mathrm{I}^{-1} ; 8$, Acide glutamique 8,7 mmol..$^{-1} ; 9$, Glycine 2,5 mmol. $\mathrm{t}^{-1} ; 10$, Histidine 1,9 mmol. $\mathrm{t}^{-1} ; 11$, Isoleucine 4,7 mmol..$^{-1} ; 12$, Leucine 7,4 mmol..$^{-1} ; 13$, Lysine 5,6 mmol..$^{-1} ; 14$, Méthionine 2,1 mmol..$^{-1} ; 15$, Phénylalanine 3,3 mmol..$^{-1}$; 16, Proline 10,2 mmol..$^{-1} ; 17$, Sérine $6,8 \mathrm{mmol}^{-1} ; 18$, Thréonine 3,8 mmol..$^{-1} ; 19$, Tryptophane 0,6 mmol..$^{-1} ; 20$, Tyrosine 3,4 mmol..$^{-1} ; 21$, Valine $6,2 \mathrm{mmol}^{-1^{-1}}$. 
was prolonged when histidine, methionine, cysteine, asparagine, arginine or alanine was included in the growth medium. On the other hand, alanine, asparagine, glycine and proline had an inhibitory effect on proteinase production. Arginine, histidine, phenylalanine and valine did not affect it and tyrosine, tryptophan, threonine, serine, methionine, lysine, leucine, isoleucine, glutamic acid, glutamine and especially cysteine enhanced proteinase production. Similar behaviour was observed for specific activity. It was felt that cysteine might prevent the loss of proteolytic activity observed when cultures were grown on gelatin. However, addition of cysteine at concentrations ranging from $0-5 \mathrm{mM}$ to cultures on reaching the stationary phase $(40 \mathrm{~h})$ had no effect on extracellular proteinase stability in comparison to the control (without added cysteine), ie all batches lost activity to the same extent.

\section{DISCUSSION}

Based on the tests made, Micrococcus GF had all the characteristics of $M$ luteus except that it did not grow on inorganic nitrogen agar; therefore, without a more extensive taxonomic study, it was not possible to identify this strain to species level.

The optimum temperature for the growth of Micrococcus GF was $\approx 30^{\circ} \mathrm{C}$. This temperature was also reported as optimal for the growth of and proteinase production by Micrococcus sp MCC-315 (Prasad et al, 1984). However, McDonald (1961) reported $25^{\circ} \mathrm{C}$ as the optimum temperature for both growth of and proteinase production by Micrococcus ATCC 407. Proteinase production by Micrococcus GF did not vary significantly in the range 26$37^{\circ} \mathrm{C}$.

Aeration during growth reduced the generation time and also enhanced protei- nase production. Similar results were reported for $M$ freudenreichii (Husain and McDonald, 1958), for a Micrococcus sp (McDonald, 1960), for $M$ sodonensis (reclassified as $M$ luteus (Baird-Parker, 1974)) (Mills and Campbell, 1974) and for a Micrococcus sp, which produced proteinase only when aerated (Prasad et al, 1984).

Micrococcus GF grew optimally in $2 \%$ phytone peptone, while proteinase production was very similar in the range $1-2 \%$. Nigan et al (1981) reported optimum growth of $P$ aeruginosa in $4 \%$ peptone, but growth in $1 \%$ peptone gave the highest proteolytic activity. The organism did not grow in the presence of either $0.4 \%$ glucose or maltose with $\mathrm{NH}_{4} \mathrm{Cl}$ as the sole $\mathrm{N}$ source. Prasad et al (1984) reported that Micrococcus MCC-315 did not use glucose, sucrose, fructose, lactose, galactose, xylose, arabinose or mannitol when grown in tryptone-yeast extract broth and none of the sugars affected proteinase production, while maltose had a strong inhibitory effect on proteinase production. Proteinase production by Micrococcus GF was not affected by glucose, but maltose had a weak inhibitory effect. There is evidence for general catabolite repression of proteinase synthesis by easily metabolised carbon sources (eg Juffs, 1976; Hare et al, 1981).

Low concentrations $(2 \%)$ of $\mathrm{NaCl}$ stimulated the growth of Micrococcus GF. A similar effect was reported for Micrococcus ATCC 407 by McDonald (1961). However, proteinase production by Micrococcus GF was suppressed by $\mathrm{NaCl}$. Prasad et al (1984) reported that proteinase production by Micrococcus MCC-315 was stimulated by adding up to $1 \% \mathrm{NaCl}$ to the medium. Proteinase production by Micrococcus ATCC 407 was optimal when the medium contained $2 \% \mathrm{NaCl}$ and several salts, including $\mathrm{NaCl}$, when added to the cell-free 
supernatant at $\approx 0.25 \mathrm{M}$ reduced the rate of enzyme inactivation (McDonald, 1961); therefore, from the data presented it is not possible to conclude whether $\mathrm{NaCl}$ stimulated proteinase production or prevented its inactivation during growth.

Micrococcus GF did not use $\mathrm{NH}_{4} \mathrm{Cl}$ as the sole $\mathrm{N}$ source in presence of glucose or maltose; a similar observation was made by Campbell et al (1962) for $M$ sodonensis. Glutamine and glutamic acid were the only amino acids which Micrococcus GF could use as the sole $\mathrm{C} / \mathrm{N}$ source. This capacity has been reported for other micrococci, eg Micrococcus ATCC 407 (McDonald, 1961), $M$ roseus and $M$ luteus (Kocur, 1986). This demonstrates that extracellular proteinase production by Micrococcus GF and other micrococci does not need the presence of protein as inducer.

Micrococcus GF grew and secreted proteinase(s) on all the complex media tested. Growth was faster on casaminoacids or phytone peptone or gelatin plus casaminoacids than on gelatin; however, the final bacterial population was similar on the 4 media. More marked differences were observed in proteinase production. Extracellular proteolytic activity was maximal at the end of the exponential phase and decreased markedly thereafter when amino acids or gelatin were the sole $\mathrm{C} / \mathrm{N}$ source. However, proteinase production increased until the end of exponential and stationary phases when either $1 \%$ or $2 \%$ phytone peptone or a mixture of casaminoacids $(1 \%)$ and gelatin (1\%) was the $\mathrm{C} / \mathrm{N}$ source and activity did not decrease thereafter. To establish whether individual amino acids might "protect" or induce extracellular proteinase production by Micrococcus GF growing on gelatin, individual amino acids were added to gelatin, but none of the amino acids, at the concentrations tested, was able to simulate the "protective" or inducer effect observed when gelatin was fortified with casaminoacids ( $1 \%)$, although some individual amino acids, especially cysteine, did improve proteinase production. This may be explained by the reducing capacity of cysteine, which, together with other amino acids, may protect the enzyme against inactivation. Cysteine inhibits bacterial growth, a fact observed in the present study.

$\mathrm{NH}_{4} \mathrm{Cl}(0.1 \%)$ inhibited the growth of $\mathrm{Mi}$ crococcus GF (see table II). The glutamine transport activity in $E$ coli (Willis et al, 1975 ) and $S$ typhimurium (Betteridge and Ayling, 1976) is very low in rich medium and is maximally derepressed only when the medium contains a poor source of nitrogen such as glutamate; glutamine does not cause repression, but free $\mathrm{NH}_{4}{ }^{+}$is an excellent repressor (Oxender et al, 1980). Similar observations have been made for yeast; eg the amino acid transport system of Saccharomyces cerevisiae is inhibited by $\mathrm{NH}_{4}{ }^{+}$(Grenson et al, 1970). The repressor effect of $\mathrm{NH}_{4}{ }^{+}$on transport systems may explain the increased generation times measured when this ion was present in the culture medium. However, $\mathrm{NH}_{4}{ }^{+}$did not affect proteinase production. A repressor effect of $\mathrm{NH}_{4}{ }^{+}$on proteinase production has been reported for the synthesis of extracellular collagenase and alkaline proteinase by Vibrio alginolyticus (Hare et al, 1981).

Proteinase production by Micrococcus GF was influenced by the organic $N$ source used. In contrast, proteinase production by $M$ sodonensis was independent of the organic $\mathrm{N}$ source (Mills and Campbell, 1974). In some bacteria, amino acids and/or peptides appear to induce extracellular proteinase production. This fact presumably accounts for proteinase production during exponential growth (Law, 1980). Micrococcus ATCC 407 produced small amounts of extracellular proteinase in a synthetic medium containing methio- 
nine, thiamine, biotin, $\mathrm{NH}_{4} \mathrm{Cl}, \mathrm{NaHCO}_{3}$, $\mathrm{NaCl}, \mathrm{MgSO}_{4}, \mathrm{FeSO}_{4}$ and maltose and any one of several amino acids stimulated growth and proteinase production (McDonald and Chambers, 1966). In the case of Micrococcus GF, a mixture of low and high molecular weight $\mathrm{N}$ compounds may be necessary for maximum proteinase(s) production since more enzyme was detected when Micrococcus GF grew on either phytone peptone or casaminoacids plus gelatin than on glutamine, glutamic acid, casaminoacids or gelatin, separately, or on gelatin plus all individual amino acid as the sole $\mathrm{C} / \mathrm{N}$ sources. McDonald and Chambers (1966) suggested that the function of the extracellular proteinase of Micrococcus ATCC 407 was to ensure a supply of carbon for growth rather than a supply of amino acids for protein synthesis. The extracellular proteolytic activity of Micrococcus GF appears to have the same function.

\section{ACKNOWLEDGMENTS}

Many thanks are due to $C N$ Luasaigh for providing the strain for this investigation. G de Fernando's work was supported by a grant from the Universidad Complutense de Madrid, Spain.

\section{REFERENCES}

Baird-Parker AC (1974) Micrococcus. In: Bergey's Manual of Determinative Bacteriology (Buchanan RE, Gibbons NE, eds) Williams and Wilkins Co, Baltimore, USA, 8th edn, 478-483

Betteridge PR, Ayling PD (1976) The regulation of glutamine transport and glutamine synthetase in Salmonella typhimurium. J Gen Microbiol 95, 324-334

Campbell JN, Evans JB, Perry JJ, Niven CF Jr (1962) Effect of ammonium ion on growth and metabolism of Micrococcus sodonensis. $\checkmark$ Bacteriol 82, 823-827
Garcia de Fernando GD, Fox PF (1991) Extracellular proteinases from Micrococcus GF: II. Isolation and characterization. Lait 71, 371 382

Grenson M, Hou C, Crabeel M (1970) Multiplicity of the amino acid permeases in Saccharomyces cerevisiae. IV. Evidence for a general amino acid permease. $J$ Bacteriol 103, 770 777

Hammer B, Babel FJ (1957) Dairy Bacteriology. John Wiley \& Sons Inc, NY, 4th edn, 213-214

Hare P, Long S, Robb FT, Woods DR (1981) Regulation of exoprotease production by temperature and oxygen in Vibrio alginolyticus. Arch Microbiol 130, 276-280

Husain I, McDonald IJ (1958) Characteristics of an extracellular proteinase from Micrococcus freudenreichii. Can J Microbiol 4, 237-242

Juffs HS (1976) Effect of temperature and nutrients on proteinase production by Pseudomonas fluorescens and $P S$ aeruginosa in broth and milk. J Appl Bacteriol 40, 23-32

Kocur M (1986) Genus I. Micrococcus. In: Bergey's Manual of Systematic Bacteriology (Sneath PHA, Mair NS, Sharpe ME, Holt JG, eds) Williams and Wilkins Company, Baltimore, USA, vol 2, 9th edn, 1004-1008

Law BA (1980) Transport and utilization of proteins by bacteria. In: Microorganisms and Nitrogen Sources (Payne JW ed).John Wiley and Sons, Chichester, UK, 381-409

McDonald IJ (1960) A minimal synthetic medium supporting growth of Micrococcus sp. Can J Microbiol 6, 251-256

McDonald IJ (1961) Proteinase production in relation to growth of a Micrococcus sp. Can J Microbiol 7, 111-117

McDonald IJ, Chambers AK (1966) Regulation of proteinase formation in a species of Micrococcus. Can J Microbiol 12, 1175-1185

Mills C, Campbell JN (1974) Production and control of extracellular enzymes in Micrococcus sodonensis. Can J Microbiol 20, 81-90

Nelson FE (1981) The microbiology of market milk. In: Dairy Microbiology. Vol 1. The Microbiology of Milk (Robinson RK, ed) Appl Sci Publ, London, UK, 190-194

Nigan JN, Pillai KR, Baruah JH (1981) Effect of carbon and nitrogen sources on neutral pro- 
teinase production by Pseudomonas aeruginosa. Folia Microbiol 26, 358-363

Oxender DL, Quay SC, Andersson JT (1980) Regulation of amino acid transport. In: Microorganisms and Nitrogen Sources (Payne JW, ed) John Wiley and Sons, Chichester, UK, 153-169

Prasad R, Malik RK, Mathur DK (1984) Optimization of nutritional and environmental factors for the production of caseinolytic en- zyme of a Micrococcus sp isolated from Cheddar cheese. Asian J Dairy Res 3, 25-36

Robertson PS, Perry KDS (1961) Enhancement of flavor of Cheddar cheese by adding a strain of Micrococcus to the milk. J Dairy Res $28,245-253$

Willis RC, Iwata KK, Furlong CE (1975) Regulation of glutamine transport in Escherichia coli. J Bacteriol 122, 1032-1037 